\title{
DIOGenes: an integrated multidisciplinary approach to the obesity problem in Europe
}

Citation for published version (APA):

Saris, W. H. M. (2005). DIOGenes: an integrated multidisciplinary approach to the obesity problem in Europe. Nutrition Bulletin, 30,1-6. https://doi.org/10.1111/j.1467-3010.2005.00496.x

Document status and date:

Published: 01/01/2005

DOI:

10.1111/j.1467-3010.2005.00496.x

Document Version:

Publisher's PDF, also known as Version of record

\section{Please check the document version of this publication:}

- A submitted manuscript is the version of the article upon submission and before peer-review. There can be important differences between the submitted version and the official published version of record.

People interested in the research are advised to contact the author for the final version of the publication, or visit the DOI to the publisher's website.

- The final author version and the galley proof are versions of the publication after peer review.

- The final published version features the final layout of the paper including the volume, issue and page numbers.

Link to publication

\footnotetext{
General rights rights.

- You may freely distribute the URL identifying the publication in the public portal. please follow below link for the End User Agreement:

www.umlib.nl/taverne-license

Take down policy

If you believe that this document breaches copyright please contact us at:

repository@maastrichtuniversity.nl

providing details and we will investigate your claim.
}

Copyright and moral rights for the publications made accessible in the public portal are retained by the authors and/or other copyright owners and it is a condition of accessing publications that users recognise and abide by the legal requirements associated with these

- Users may download and print one copy of any publication from the public portal for the purpose of private study or research.

- You may not further distribute the material or use it for any profit-making activity or commercial gain

If the publication is distributed under the terms of Article $25 \mathrm{fa}$ of the Dutch Copyright Act, indicated by the "Taverne" license above, 


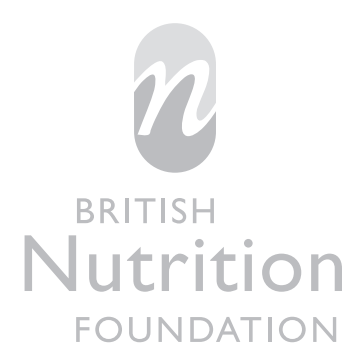

NEWS FROM EU RESEARCH

W. H. M. Saris

NUTRIM, University of Maastricht, The Netherlands

The rapid increase in the prevalence of obesity and associated co-morbidities is a major global health problem. In Europe obesity directly consumes about $5 \%$ of total health care budgets. Of greater societal concern is the rapid increase in childhood obesity afflicting all European countries. Recognising the urgency of the obesity problem, the European Council of Ministers called for action in 2002. Although obesity is in principle a simple problem of energy imbalance, there remain questions relating to identifying and delivering the most effective individual guidance and tools for preventing weight gain. Whilst there is considerable genetic variance in individual susceptibility to obesity, the current obesity epidemic is significantly influenced by adverse lifestyle factors. Given our general genetic background, it appears very difficult for humans to self-regulate food intake under current environmental circumstances. This worrying trend has challenged the scientific community to expand its research efforts using a wide variety of innovative approaches.

\section{The DiOGenes project}

DiOGenes is the acronym for a five-year research project, starting in January 2005, which will address some of the key issues linking Diet, Obesity and Genes. It involves a consortium of 30 partners from 15 European countries, including 23 research institutions, four SMEs (small and medium-sized enterprises) and three multinational food companies. The project is funded under the Food Quality and Safety Priority of the Sixth Framework Programme for Research and Technological Development of the European Union. It is coordinated

Correspondence: Professor Wim H. M. Saris, NUTRIM, University of Maastricht, PO Box 616, 6200MD Maastricht, The Netherlands. E-mail: W.Saris@HB.unimaas.nl by the nutrition research institute NUTRIM, University of Maastricht, The Netherlands.

DiOGenes is an integrated programme aimed at identifying key dietary, psychological, lifestyle and genetic factors, as well as bio-markers, which will provide a scientific basis for predicting whether a subject will keep a healthy weight or not. The project's ultimate goal is to use the new knowledge generated to stimulate innovation in both foods and dietary advice to help minimise the risks of overweight and obesity among European consumers.

\section{Overview of evidence linking diet, genetics, behaviour and weight development}

\section{Dietary factors}

A reduction in dietary fat content under ad libitum conditions produces a modest but clinically important weight loss in 6 months of active intervention, but it is clear that the non-fat component of the diet is also critically important (Saris et al. 2000).

The glycaemic index (GI) of carbohydrates affects cardiovascular risk factors and glycaemic control in diabetics, and may play a role in appetite control (Pawlak et al. 2002). A number of studies suggest that replacing high GI foods with similar low GI foods can reduce passive over consumption of energy or lead to a greater loss of fat compared with lean body tissue during dieting (Pawlak et al. 2002; Willet 2002). The literature, however, is inconclusive. One of the major issues is whether it really is the glycaemic response to these foods that is important, or other characteristics of low GI foods, which tend to be higher in fibre and protein, and lower in sugars and energy density. Many studies suffer from lack of good dietary control, poor measures of dietary compliance, a lack of statistical power to detect weight changes of clinical relevance, or feeding of single sugars as opposed to real multi-ingredient foods. A further 
problem is the reproducibility of the measurement of GI itself: GI is affected by, for exmaple, fruit ripeness, food particle size, cooking methods, etc. (Pi-Sunyer 2002).

Ad libitum diets with higher protein content have been shown to enhance satiety and increase thermogenesis in a number of smaller studies, and to produce better weight control and weight loss than diets in which the protein is replaced by carbohydrate (Skov et al. 1999; Eisenstein et al. 2002). A previous 12-month study found that a fat-reduced diet with high compared with normal protein appeared to enhance weight loss and provide a greater reduction in intra-abdominal fat stores. However, this pilot study did not have the statistical power to assess weight differences between groups after 12 months due to inadequate numbers of subjects (Due et al. 2004). These high-protein diets challenge the current recommendations and need to be evaluated for efficacy and safety, particularly in children, in a large, long-term, strictly controlled intervention trial (Eisenstein et al. 2002).

\section{Genetic and environmental factors}

According to current models, susceptibility to obesity is determined largely by genetic factors, but the environment determines phenotypic expression. Heritability estimates range between 50 and $90 \%$, indicating that genetic factors account for a substantial proportion of variation around the mean in human adiposity (Hebebrand et al. 2001). These genetic determinants are multiple and interacting with each other and with the environment (Bell et al. 2005). Despite encouraging findings (Hager et al. 1998), no gene has been formally identified for common obesity.

Numerous studies have addressed the characteristics of subjects that determine the risk of development of obesity at a population level (WHO 1998). There is no doubt that there is strong genetic predisposition, which fully accounts for the resemblance in degree of fatness or occurrence of obesity in biologically related adults living apart (Maes et al. 1997). There is equally strong evidence that environmental factors in general, whether or not shared by family members, determine the differences in occurrence of obesity and weight gain both within and between populations. A coherent understanding of these environmental factors is still lacking (WHO 1998), probably because weight gain in a single individual is influenced by multiple, possibly interacting, factors, several of which may be under both genetic and environmental control, may vary over time, and may themselves be influenced by the changes in weight as they occur, for example physical activity and diet in terms of both amount and composition (Colditz et al. 1990; Koh-Banerjee et al. 2003). So far, there is no clearcut evidence from prospective population studies that points to specific dietary components as major factors in the development of obesity (Togo et al. 2001; Newby et al. 2003). Much attention has been focused on fat content of the diet based on both animal and human experimental work, but in large population databases the associations have been demonstrated convincingly only in cross-sectional studies (Seidell 1998; Lissner et al. 2000). A limitation of studies like these on the factors influencing weight gain and development of obesity is that they appear to have been too small compared with the inherent variation and interaction in the measurement and occurrence of the factors involved.

\section{Gene-diet interactions}

Data are also scarce on the interaction of genes and diets. The novel tools of functional genomics can readily be applied to the study of nutrient-gene interactions in the context of obesity. DNA and RNA microarrays have allowed identification of specific gene expression profiles in animal models (Nadler et al. 2000), but can also be readily applied to clinical studies (Clément et al. 2004).

Adipose tissue, as an endocrine organ, is a good target for transcriptomics experiments. It senses metabolic signals and secretes peptide hormones that regulate whole-body energy homeostasis. Dysregulation of adipocyte-derived peptides may affect insulin sensibility. Transcriptomics approaches on adipose tissue are therefore ideally complemented by proteomics technologies focusing on circulating peptides (Jurgens \& Schrader 2002).

\section{Behavioural factors}

Despite market-place success, strategies to increase consumption of low-fat foods (IFIC 1997) have produced mixed evidence that they prevent weight gain in the longer term. The majority of those who lose weight cannot control or sustain the loss (Garrow 1998). In reality, consumers choose and select dietary approaches to weight management for a variety of reasons. The major influences on these choices relate to prevailing attitudes and perceptions, psychological and psychosocial aspirations, and the actual behaviours the consumers themselves engage in. It is this psychosocial context that moulds food habits and weight control capability. A consumer will only adopt a new approach to weight management if it fits with his or her attitudes and per- 
ceptions, including any perceived barriers, to effective weight control. In order to maximise the potential value of any weight control strategy, whether dietary or otherwise, it has become essential to learn about the features and behaviours of those who can and cannot easily control their weight, so that strategies can be better tailored to fit the psychosocial profile of different consumers.

\section{Food technology}

The normal paradigm of the food and flavour industries has been to maximise consumers' liking for a food, with the goal to increase purchase of specific products or brands. It seems equally possible that foods could combine consumer liking with limitation of intake due to enhanced satiety or satiation signals. There are several examples. Energy intake is positively correlated with energy density of a food, and thereby with its macronutrient composition and water content. As such, inclusion of selected fibres in a normal staple food like pasta may be used to lower energy density and thus unconsciously lower energy intake (Westerterp-Plantenga 2001). Another potential trigger is monosodium glutamate (MSG). It is possible that a dosage of MSG slightly higher than normally used in foods will cause an increased sensory-specific satiation effect (Bellisle 1999). Protein content of the food has been found to influence perceived long-term satiety (Gerstein et al. 2004).

It is possible that differences between consumers in taste perception (i.e. sensitivity profiles to specific tastants) may influence development of satiation and food intake behaviour. The hypothesis needs to be tested. Recent research linking sensitivity to tastants and textural liking provides some intriguing observations. For example, studies show that differences in taste sensitivity to 6-n-propylthiouracil (PROP) or fatty acids correlate with differences in perception of desirable creamy sensations or fat preferences (Tepper \& Nurse 1997; Nasser et al. 2001; Keller et al. 2002; De Wijk \& Weenen 2004; Smeets et al. 2004). Clearly, such relations, and their potential role in regulating food intake in the overweight or obese individual, need to be further explored. To do so requires a new combination of the skills of physiology, psychology and food technology.

\section{The DiOGenes programme}

DiOGenes will undertake an integrated programme of new studies in each of the five areas reviewed above. The programme should yield outputs of two types. The first will be new insights into the links between diet, genetics and development of overweight/obesity. The second will be indications from the psychology and food technology studies on how the new insights can be applied to achieve real benefit for consumers at risk from overweight/obesity.

The programme will be divided into five RTD lines ('Research, Technology and Development'), supported by a common data-hub and a programme of dissemination, innovation and training.

\section{RTD1: obesity and macronutrient composition of the diet}

The primary focus of DiOGenes is a dietary intervention study to be executed in eight different centres across Europe - in Denmark, The Netherlands, UK, Germany, Spain, Greece, Bulgaria and The Czech Republic. This study will explore the role of GI and dietary protein as two key factors which may promote satiety and control of energy intake.

The volunteer subjects will be families with at least one obese parent [body mass index (BMI) $>30$ ] and one overweight child; the other parent will be overweight (BMI > 28). A total of 900 subjects in 350 families will be involved. Initially all adult volunteers will follow an 8 week very low calorie weight-loss diet, and any family in which at least one parent loses $8 \%$ of initial body weight will be randomised to one of five dietary intervention arms: high GI/normal protein, low GI/high protein, high protein/high GI, normal protein/low GI and control. The factorial design allows interaction between dietary components to be assessed.

The dietary intervention will be followed for 6 months at 6 of the 8 centres where subjects will receive dietary advice, and for 12 months at the other 2 centres, where families will buy all groceries from an on-site supermarket for the first 6 months (thus aiding compliance). During the study the volunteers will keep regular detailed 7-day food records. The researchers will measure body weight and composition, and take samples of blood, urine and adipose tissue to measure appetite hormones, and to assess risk of both cardiovascular disease/diabetes and the high protein diet, particularly in children. Some of the samples will also be used in RTD2 to study genetic variation between subjects and gene-nutrient interactions, to help predict which people could be most susceptible to weight regain after a period of weight loss. Collaboration with RTD4 will also identify psychological and behavioural markers such as physical activity levels that help to predict risk of weight gain. 


\section{RTD2: obesity and gene-nutrient interaction}

The DiOGenes intervention study provides a unique opportunity to study gene-nutrient interactions associated with changes in body weight in order to reach a better understanding of how obesity can be prevented and treated from a dietary perspective.

Three complementary approaches will be used: Genetic approach

This aspect of the work will involve building a database of nutrient-sensitive genes and variations in genetic markers (SNPs). This database will be integrated into the central data collection facility for the project as a whole. From this database candidate genes will be selected for genotyping of the subjects in RTD1 and selected subgroups from RTD3.

\section{Transcriptomics approach}

Adipose tissue is biologically very active, and secretes various peptide hormones that help to control energy. Adipose tissue samples taken from some of the RTD1 volunteers will be used to identify genes that predict weight change and nutritional status through these hormones, using a transcriptomics approach.

\section{Peptidomics approach}

Plasma samples from some of the obese RTD1 volunteers will be used to determine the level of circulating peptides at baseline, after weight loss and at the end of the dietary intervention. Peptides that predict weight change and nutritional status will be identified using a peptidomics approach.

\section{RTD3: obesity, genes and diet at the population} level

Complementing the studies in RTD1 and 2, DiOGenes will carry out a large-scale population-based cohort study, involving 145000 adult men and women from five EU countries. The populations will be drawn from five existing EPIC cohorts. The main objective of this epidemiological approach is to evaluate the roles of two key dietary factors, GI and protein, in preventing the development of overweight, obesity and related comorbidities, at the general population level and in a long-term perspective. Specific objectives will be to identify:

- key dietary factors that determine risk of overweight in the future using 5 years of follow-up data;
- the relationships between key dietary factors and genetic predisposition to obesity (using SNP data from RTD2 on subgroups of subjects selected on the basis of weight increase or weight stability from the baseline measurement to follow-up);

- the risk of the development of obesity attributable to the two dietary factors, in a public health perspective;

- the quantitative genetic, shared and non-shared environmental influences on the key dietary factors and the development of obesity. Data from pre-existing Danish and Finnish twin cohorts will be merged and analysed. Clinical data will be obtained from 1000 twin pairs, and questionnaire-based information from 5000 twin pairs.

\section{RTD4: obesity, consumer attitudes and behaviour}

The RTD1 intervention study also provides opportunities to identify psychological and behavioural markers that help to predict risk of weight gain and better match diets to consumer needs. RTD4 will develop tools to identify behaviours that increase the risk of weight regain after weight loss. These tools will include methods for:

- assessing consumer expectations of weight loss;

- determining the psychological and behavioural responses to weight loss and weight control;

- documenting attitudes and perceptions about, and barriers to, weight control;

- identifying feeding and drinking behaviours, as well as activity patterns, that predict successful weight control;

- understanding the relative contribution of liking food, and hunger, to changes in feeding behaviour;

- measuring energy expenditure and physical activity patterns in free-living people.

These tools will be implemented during the intervention study, at baseline, after weight loss and at the end of the intervention period. The results will be used to develop a software-based obesity risk and behavioural advice screening tool (ORBAST) to help consumers and health care professionals devise personalised lifestyle approaches, to help reduce the risk of overweight and obesity.

\section{RTD5: obesity and food technology}

Studies linking physiology, psychology and food technology will explore opportunities for food product development as a route to extend DiOGenes' dietrelated findings into practical solutions for consumers. Initially, psycho-physiological studies will investigate 
the relationship between perception and physiological responses, which will provide the scientific basis for identifying new triggers for inducing satiation. These triggers could include physiological status, specific ingredients, flavours and aromas. As part of the studies, new methodology will be developed to observe noncognitive responses to food intake such as changes in temperature, heart rate, reflexes, speed, frequency and duration of food intake.

Findings about triggers for satiation will then facilitate the tailored development, and prototype production, of new food products. The focus for product development will be foods that are high/low in protein and carbohydrates, and include food-grade satiationinducing triggers, with special emphasis on consumer liking and preferences.

\section{RTD6}

A central project data-hub will be created to maximise the integration between RTD lines, standardisation of protocols and data collation, storage of (and remote access to) the data from the RTD lines, and rapid, detailed analysis and modelling of complex data sets.

\section{RTD7}

This line will support DiOGenes in the areas of dissemination, innovation, demonstration and training. Its task will be to facilitate the flow of new knowledge from the project into practical innovation (new products, services or advice), into deployment in the scientific community (new expertise and techniques), and to consumers and opinion leaders across Europe.

Further information on DiOGenes can be found at http://www.diogenes-eu.org

DiOGenes is one of a portfolio of initiatives, including Integrated Projects and Networks of Excellence, funded by the EU in the area of food safety and health. Nutrition Bulletin has already reviewed several, including the Lipgene project (Nugent 2004) and NuGo (Astley \& Elliott 2004), and will cover others in future issues.

\section{References}

Astley SB \& Elliott RM (2004) The European Nutrigenomics Organisation - linking genomics, nutrition and health research. Nutrition Bulletin 29: 254-61.

Bell CG, Walley AJ \& Froquel F (2005) The genetics of human obesity. Nature Reviews Genetics, AOP, published online 10 February 2005 .
Bellisle F (1999) Glutamate and the UMAMI taste: sensory, metabolic, nutritional and behavioural considerations. A review of the literature published in the last 10 years. Neuroscience and Biobehavioural Reviews 23: 423-38.

Clément K, Viguerie N \& Poitou C et al. (2004) Weight loss regulates inflammation-related genes in white adipose tissue of obese subjects. The Federation of American Societies for Experimental Biology Journal 18: 1657-69.

Colditz GA, Willett WC, Stampfer MJ et al. (1990) Patterns of weight change and their relation to diet in a cohort of healthy women. American Journal of Clinical Nutrition 51: 1100-5.

De Wijk RA \& Weenen H (2004) PROP taster status versus texture and flavor sensations for low-fat semi-solid foods. Presentation at the Achems Conference Held in Sarasota, Fl, April 22-25, 2004.

Due A, Toubro S, Skov AR et al. (2004) Effect of normal-fat diets either medium or high in protein, on body weight in overweight subjects; a randomised 1-year trial. International Journal of Obesity 28: 1283-90.

Eisenstein J, Roberts SB, Dallal G et al. (2002) High-protein weightloss diets: are they safe and do they work? A review of the experimental and epidemiologic data. Nutrition Reviews 60 (7): 189-200.

Garrow JS (1998) Obesity and Related Diseases, Chapter 8. Churchill Livingstone: London.

Gerstein DE, Woodward-Lopez G, Evans AE et al. (2004) Clarifying concepts about macronutrients' effects on satiation and satiety. Journal of the American Dietetic Association 104: 1151-3.

Hager J, Dina C, Francke C et al. (1998) A genome-wide scan for human obesity genes reveals a major susceptibility locus on chromosome 10. Nature Genetics 20: 304-8.

Hebebrand J, Sommerlad C, Geller F et al. (2001) The genetics of obesity: practical implications. International Journal of Obesity 25: S1: S10-18.

International Food Information Council (1997) IFIC (International Food Information Council) Foundation Review, Uses and Nutritional Impact of Fat Reduction Ingredients. Washington DC.

Jurgens M \& Schrader M (2002) Peptidomic approaches in proteomic research. Current Opinion in Molecular Therapeutics 4: 236-41.

Keller KL, Steinmann L, Nurse RJ et al. (2002) Genetic taste sensitivity to 6-n-propylthiouracil influences food preference and reported intake in preschool children. Appetite 38: 3-12.

Koh-Banerjee P, Chu N-F, Spiegelman D et al. (2003) Prospective study of the association of changes in dietary intake, physical activity, alcohol consumption, and smoking with 9-y gain in waist circumference among 16,587 US men. American Journal of Clinical Nutrition 78: 719-27.

Lissner L, Heitmann BL \& Bengtsson C (2000) Population studies of diet and obesity. British Journal of Nutrition 83: S21-S24.

Maes HHM, Neale MC \& Eaves LJ (1997) Genetic and environmental factors in relative body weight and human adiposity. Behavior Genetics 27: 325-51.

Nadler ST, Stoehr JP, Schueler K et al. (2000) The expression of adipogenic genes is decreased in obesity and diabetes mellitus. Proceedings of the National Academy of Science of the USA 97: 11371-6.

Nasser JA, Kissileff HR, Boozer CN et al. (2001) PROP taster status and oral fatty acid perception. Eating Behaviors 2: 237-45.

Newby PK, Muller D, Hallfrisch J et al. (2003) Dietary patterns and changes in body mass index and waist circumference in adults. American Journal of Clinical Nutrition 77: 1417-25. 
Nugent A (2004) LIPGENE: a truly integrated approach to tackling the metabolic syndrome. Nutrition Bulletin 29: 152-5.

Pawlak DB, Ebbeling CB \& Ludwig DS (2002) Should obese patients be counselled to follow a low-glycaemic index diet? Yes. Obesity Reviews 3 (4): 235-43.

Pi-Sunyer FX (2002) Glycaemic index and disease. American Journal of Clinical Nutrition 76 (1): 290S-298S.

Saris WHM, Astrup A \& Prentice AM (2000) Randomized controlled trial of changes in dietary carbohydrate/fat ratio and simple vs. complex carbohydrates on body weight and blood lipids. The CARMEN study. International Journal of Obesity 24: 1310-8.

Seidell JC (1998) Dietary fat and obesity: an epidemiologic perspective. American Journal of Clinical Nutrition 67 (Suppl. 3): 546S550 S.

Skov AR, Toubro S, Ronn B et al. (1999) Randomized trial on protein vs. carbohydrate in ad libitum fat reduced diet for the treatment of obesity. International Journal of Obesity 23: 528-36.
Smeets M, Weenen H, de Wijk RA et al. (2004) Influence of fatty acid sensitivity on taste perception. Presentation at the Achems Conference Held in Sarasota, Fl, April 22-25, 2004.

Tepper BJ \& Nurse RJ (1997) Fat perception is related to PROP taster status. Physiology and Behavior 61: 949-54.

Togo P, Osler M, Sørensen TIA et al. (2001) Food intake patterns and body mass index in observational studies. International Journal of Obesity 25: 1741-51.

Westerterp-Plantenga MS (2001) Analysis of energy density of food in relation to energy intake regulation in human subjects. British Journal of Nutrition 85: 351-61.

Willet WC (2002) Eat, Drink, and Be Healthy: the Harvard Medical School Guide to Healthy Eating. Simon \&. Schuster, New York.

World Health Organization (1998) Obesity: Preventing and Managing the Global Epidemic. Report of the WHO Consultation of Obesity. World Health Organization, Geneva. 